\title{
PERBANDINGAN HUBUNGAN SIPIL-MILITER DI INDONESIA PADA MASA ABDURRAHMAN WAHID DENGAN ERDOGAN DI TURKI
}

\author{
Mhd. Alfahjri Sukri \\ Institut Agama Islam Negeri Batusangkar \\ Jalan Jenderal Sudirman, Lima Kaum, Kabupaten Tanah Datar, \\ Pos-el: malfahjrisukri@iainbatusangkar.ac.id
}

\begin{abstract}
This paper aims to compare civil-military relations in Indonesia during Abdurrahman Wahid's (19992001) period with Turkey during Erdogan's (2003-2011) by looking at civilian control over the military. The study looks at the differences and similarities between the two countries and the causes of Erdogan's success and Abdurrahman Wahid's failure to control the military. In this research, the author used qualitative approach. The results showed that there were similarities and differences in civil-military relations between Gus Dur and Erdogan, as seen from civil control over the military. The similarities could bee seen at the beginning of their reign. Abdurrahman and Erdogan had strong civilian control over the military, so that they could reduce the military's role in politics with various policies issued. This strong control is also supported by political conditions, political elites, and society. However, there were differences in civil-military relations at the end of the Gus Dur and Erdogan governments. Civilian control over the military weakened at the end of the Gus Dur's reign which caused him to fall from his position as the President of Republic of Indonesia, whereas Erdogan's civilian control over military was getting stronger. The failure factor for Abdurrahman to strengthen civilian control over the military was a radical change. In contrast to Erdogan who made changes gradually with the support of politics and society.
\end{abstract}

Keywords: Turkey; Indonesia; Abdurrahman Wahid; Erdogan; Civil-Military Relations

\begin{abstract}
Abstrak: Penelitian bertujuan untuk membandingkan hubungan sipil-militer di Indonesia pada masa Abdurrahman Wahid (1999-2001) dengan Turki pada masa Erdogan (2003-2011) dengan melihat pada kontrol sipil atas militer. Penelitian ini melihat perbedaan dan persamaan kedua negara tersebut, serta penyebab keberhasilan Erdogan dan kegagalan Abdurrahman Wahid dalam melakukan kontrol terhadap militer. Metode yang digunakan adalah metode kualitatif. Hasil dari penelitian ini menunjukkan terdapat persamaan dan perbedaan hubungan sipil-militer antara Gus Dur dengan Erdogan, yang dilihat dari kontrol sipil atas militer. Persamaannya ialah pada awal pemerintahannya, Gus Dur dan Erdogan memiliki kontrol sipil yang kuat atas militer, sehingga mereka dapat mengurangi peran militer dalam politik dengan berbagai kebijakan yang dikeluarkan. Kontrol yang kuat tersebut juga didukung oleh kondisi politik, elit politik, dan masyarakat. Namun, terjadi perbedaan hubungan sipil-militer di akhir pemerintahan Gus Dur dan Erdogan. Kontrol sipil atas militer melemah diakhir pemerintahan Gus Dur yang menyebabkan ia jatuh dari posisinya sebagai Presiden Indonesia. Berbeda dengan Gus Dur, Erdogan memili kontrol sipil atas militer yang semakin kuat. Faktor kegagalan Gus Dur memperkuat kontrol sipil atas militer adalah perubahan radikal yang dilakukannya. Berbeda dengan Erdogan yang melakukan perubahan secara bertahap dengan dukungan politik dan masyarakat.
\end{abstract}

Kata Kunci: Turki; Indonesia; Abdurrahman Wahid; Erdogan; Hubungan Sipil-Militer 

Mhd. Alfahjri Sukri: Perbandingan Hubungan Sipil-Militer Di Indonesia Pada Masa Abdurrahman Wahid Dengan Erdogan Di Turki

\section{Pendahuluan}

Berhasilnya kudeta militer yang dilakukan di Mesir (3 Juli 2013) dan gagalnya kudeta militer yang dilakukan di Turki (15 Juli 2016), menjadikan masalah hubungan sipil-militer kembali menjadi menarik untuk diteliti, termasuk hubungan sipil-militer di Indonesia. Di Indonesia sendiri pernah terjadi kudeta Militer secara tidak lansung, yaitu ketika hancurnya Orde Lama. Kekacauan politik, gagalnya kudeta oleh PKI $^{1}$ pada 1 Oktober 1965, serta memburuknya kondisi ekonomi selama tahun 1965-1966, mengakibatkan Sukarno terjungkal dari kekuasaannya. ${ }^{2}$

Hal ini menandakan munculnya militer sebagai\ kekuatan baru di Indonesia dengan ditandai dengan lahirnya Orde Baru yang dipimpin oleh Jenderal Suharto. $^{3}$ Selama Orde Baru, militer

1 TNI dan Sukarno sepakat dalam hal Demokrasi Terpimpin untuk melemahkan partaipartai yang dianggap menimbulkan kekacauan politik dalam negara, namun berbeda dalam memandang Nasakom karena menguntungkan PKI yang dianggap sebagai ancaman oleh Militer. Gagalnya kudeta PKI menjadi momentum dominasi Militer. Lihat Salim Said, Tumbuh dan Tumbangnya Dwifungsi: Perkembangan Pemikiran Politik Militer Indonesia 1958-2000, (Jakarta: Aksara Karunia, 2002), h. 54.

2 Hutang luar negeri pemerintah yang berjangka panjang dan menengah, seluruhnya mencapai US\$ 2.175 juta dan diantaranya US\$ 530 juta harus dilunasi dalam 1966. Inflasi dan lonjakan harga juga terjadi. Lihat Ulf Sundhaussen, Politik Militer Indonesia 1945-1967: Menuju Dwi Fungsi ABRI, Terj. Hasan Basari (Jakarta: LP3ES, 1986), h. 388-396

3 Abdul Haris Fatgehipon, Tentara dan Pergolakan Politik Indonesia: Membongkar Mitos 131 menguasai politik, kontrol sipil atas militer sangat lemah. Namun pada 21 Mei 1998, Orde Baru berakhir ketika konflik dalam negeri dan krisis ekonomi yang parah tidak dapat dikontrol oleh pemerintah. ${ }^{4}$ Indonesia memasuki masa transisi menuju demokrasi dengan terpilihnya Bachrudin Jusuf (BJ) Habibie sebagai Presiden.

Di masa era Presiden BJ Habibie (1998-1999) inilah peran militer dalam politik mulai menurun. Habibie melakukan kontrol atas militer secara perlahan. Namun, hal berbeda dilakukan oleh Abdurrahman Wahid (1999-2001) yang menggantikan BJ Habibie. Abdurrahman Wahid (Gus Dur) melakukan perombakan secara radikal dalam tubuh militer dan ingin membentuk kontrol sipil yang kuat atas militer. Tindakan Gus Dur ini merupakan kecerobohan yang mengakibatkan dirinya terjungkal dari kekuasaan, ketika dekritnya tidak didukung oleh militer. Pada tanggal 21 Juli 2002 dalam Sidang Instimewa, Majelis Permusyawaratan Rakyat (MPR) menggantikan Gus Dur dengan Megawati Soekarnoputri untuk menjadi Presiden. ${ }^{5}$

Melanjutkan Reformasi Internal, (Jakarta: Cahaya Pineleng, 2010), h. 73. 125-144.

4 Abdul Haris Fatgehipon, Tentara... h.

5 Yahya A. Muhaimin, Perkembangan Militer Dalam Politik Indonesia 1945-1966, (Yogyakarta: Gadjah Mada University Press, 2002),h. xxi- xxxii. 
Upaya "depolitisasi militer" yang dilakukan oleh Gus Dur, sebenarnya juga terjadi di Turki pada era Recep Tayyid Erdogan (2003-2011) $)^{6}$ perbedaannya adalah upaya yang dilakukan oleh Gus Dur gagal, namun upaya yang dilakukan Erdogan berhasil. Turki yang merupakan negara sekuler dengan peran militer sebagai penjaga ideologi Kemal (sekuler), memainkan peranan penting dalam perpolitikan di Turki. Ketika militer mengganggap pemerintahan sipil sebagai ancaman karena buruknya perekonomian, konflik internal, atau terancamnya ideologi sekuler, maka militer akan melakukan kudeta atau intervensi terhadap politik Turki.

Militer Turki telah menjadi kekuatan politik sejak Mustafa Kemal menjadi pemimpin Turki (23 Oktober 1923), namun peranan militer dalam politik diubah oleh Kemal pada tahun 1924. Sejak saat itu posisi militer hanya sebagai pengawal konstitusi dan prinsip kemalisme untuk tetap menjaga konstitusi sekuler Turki. $^{7}$ Namun, dalam perjalanannya, militer Turki telah

6 Penelitian ini hanya menganalisis dua periode kepemimpinan Erdogan sebagai Perdana Menteri Turki saat itu, hal ini dikarenakan dua periode tersebut merupakan periode krusial untuk melihat transformasi hubungan-sipil militer di Turki, karena setelah periode tersebut kontrol sipil semakin kuat atas militer, terutama setelah kegagalan kudeta militer Turki pada 2016 lalu.

${ }^{7}$ Syahrul Hidayat, Mengislamkan Negara Sekuler, (Jakarta: Prenadamedia Group, 2015), h. 81-88. melakukan beberapa kali kudeta militer pada tahun 1960, 1971, 1980, dan setengah kudeta di tahun 1997 terhadap pemerintahan Necbetin Erbakan yang dianggap membawa nilai-nilai Islam. $^{8}$ Tahun 2001, Partai Kebajikan yang dibentuk oleh Erbakan juga dibubarkan. ${ }^{9}$

Memasuki tahun 2002, dimulai babak baru dalam perpolitikan Turki. Kemenangan Partai Keadilan dan Pembangunan (Adalet ve Kalkinma Partisi-AKP) yang dipimpin oleh Erdogan di tahun tersebut memenangkan Pemilu dengan 34,2 persen suara nasional. ${ }^{10}$ Sejak saat itu AKP terus memimpin Turki. Sejak Erdogan memimpin Turki, pola hubungan sipil-militer mulai berubah, dimana kontrol sipil menjadi kuat atas militer. Kegagalan upaya kudeta tahun 2007, kemajuan ekonomi, serta hasil Referendum 2010 yang melemahkan militer dan ditangkapnya petinggi militer Turki atas upaya kudeta, menunjukkan kontrol sipil yang kuat atas militer. ${ }^{11}$

Gus Dur dengan Erdogan merupakan pemimpin sipil yang menjadi titik baru dalam melihat kontrol sipil atas

\footnotetext{
${ }^{8}$ M. Hamdan Basyar, Pertarungan dalam Berdemokrasi, (Jakarta: UI-Press, 2015), h. 52. 87.

9 M. Hamdan Basyar, Pertarungan... h. 202.

10 Syahrul Hidayat, Mengislamkan ...h.

11 Tiara Sarah Putri Sumantri, Demokratisasi Turki: Hubungan Sipil-Militer Tahun 2003-2011, (Jakarta: Universitas Indonesia (UI-Press), 2012), h. 291-292.
} 
militer di negara masing-masing. Samasama berasal dari sipil, dan keinginan untuk menciptakan kontrol sipil yang kuat atas militer. Namun, kedua pemimpin tersebut meraih hasil yang berbeda dalam membangun hubungan sipil-militer terutama dalam melakukan kontrol sipil terhadap militer. Perbandingan inilah yang dianalisis dalam penelitian ini, dengan melihat persamaan dan perbedaan hubungan sipil-militer di masa Gus Dur di Indonesia dengan Erdogan di Turki.

Kajian mengenai hubungan sipilmiliter di masa Gur Dur (1999-2001) sudah dilakukan oleh beberapa penelitian terdahulu, namun belum dilakukan perbandingan di antara ke dua tokoh tersebut. Untuk kasus di Indonesia, Muhammad Siddiq misalnya, yang mengkaji profesionalisme militer di masa Gus Dur. Dalam kajiannya, ia melihat dari sisi profesionalisme militer yang mulai berubah pada masa Gus Dur. Menurutnya, Gus Dur melakukan langkah-langkah untuk mengurangi kekuatan militer yang berbeda dari masa Orde Baru. ${ }^{12}$

Sedangkan Adam Sukarno Putra, Nurul Umamah dan Sumarno dalam penelitiannya menyebutkan, Gus Dur sendiri selama masa pemerintahannya

\footnotetext{
12 Mohammad Siddiq, "Profesionalisme Militer Pada Pemerintahan Soeharto dan Abdurrahman Wahid (Kajian Perbandingan SosialHistoris)," Jurnal Politik dan Sosial Kemasyarakatan, Vol. 11 No. 1 (2019).
}

mengambil beberapa kebijakan yang melemahkan militer dan memperkuat supremasi sipil seperti memisahkan antara Polri dan TNI, reposisi di dalam tubuh militer itu sendiri dan kebijakan lainnya. Sehingga terciptanya kontrol sipil atas militer. ${ }^{13}$

Berbeda dengan kedua penelitian di atas, penelitian ini tidak hanya melihat bagaimana hubungan sipil-militer selama masa pemerintahan Gus Dur tetapi juga melihat penyebab kegagalan Gus Dur dalam melakukan kontrol atas militer. Selain itu penelitian ini juga melakukan perbandingan dengan kepemimpinan Erdogan di Turki dalam melakukan kontrol sipil atas militer. Perbandingan ini perlu dilakukan oleh melihat persamaan dan perbedaan hubungan sipil-militer pada masa Gus Dur di Indonesia dengan Erdogan di Turki.

Penelitian ini melihat Gus Dur dan Erdogan sama-sama berhasil di awal masa pemerintahan dengan menerapkan kontrol sipil atas militer. Namun meraih hasil yang berbeda di akhir pemerintahannya. Kontrol sipil atas militer yang dilakukan Gus Dur mengalami kegagalan dan menyebabkan ia dijatuhkan dari kursi presiden. Sedangkan Erdogan diakhir jabatannya yang kedua

13 Adam Sukarno Putra, Nurul Umamah, Sumarno, "The Presiden's Political Policy Abdurrahman Wahid About Indonesia Military Years 1999-2001, Jurnal Historica, Vol. 3 No. 1 (2019) 
sebagai perdana menteri Turki berhasil memperkuat kontrolnya atas militer, bahkan kontrol tersebut makin kuat setelah kudeta militer tahun 2016 lalu. Hubungan sipil-militer yang dibangun oleh Erdogan secara bertahap membawa ia dapat melakukan kontrol atas militer. Penelitian ini berguna untuk pemimpin sipil selanjutnya dalam melakukan kontrol sipil atas militer.

\section{Metode Penelitian}

Penelitian ini menggunakan metode kualitatif. Sugiyono menyebutkan, penelitian kualitatif adalah penelitian dengan metode yang dapat digunakan dalam meneliti maupun menganalisis suatu objek yang alamiah. Menurutnya, yang menjadi instrumen kunci dalam penelitian ini adalah peneliti itu sendiri. Hasil yang diperoleh lebih ditekankan kepada makna dan analisis data yang digunakan lebih bersifat $\quad$ kualitatif. $^{14} \quad$ Cresswell menyebutkan, penelitian kualitatif adalah metode untuk memahami suatu gejala sentral serta mengeksplorasi masalah tersebut.

Data penelitian ini diperoleh melalui analisis dokumen. Sebagaimana yang dikatakan Richie dan Lewis yaitu analisis dokumen merupakan pengkajian dan analisis terhadap berbagai macam

\footnotetext{
${ }^{14}$ Sugiyono. Metode Penelitian Kuantitatif Kualitatif dan R\&D. (Bandung: Alfabeta, 2012).
}

dokumen seperti dokumen yang bersifat pribadi maupun yang bersifat umum. Analisis dilakukan untuk memahami isi dokumen serta menangkap makna di dalamnya. ${ }^{15}$ Dengan metode ini, penelitian diharapkan mampu mendeskripsikan masalah yang dibahas.

Dalam menganalisis masalah yang diangkat, penelitian ini menggunakan teori hubungan sipil-militer. Dalam melihat hubungan sipil-militer, Samuel P. Huntington menggunakan istilah "kontrol sipil objektif (objective civilian control)". ${ }^{16}$ Kontrol sipil dalam artian objektif artinya memaksimalkan profesionalisme militer yaitu adanya pembagian kekuasaan antara militer dan kelompok-kelompok sipil untuk menciptakan situasi kondusif bagi munculnya sikap dan prilaku profesional diantara para anggota koprs perwira. ${ }^{17}$ Adapun kontrol subyektif adalah upaya sipil untuk mempolitisasi militer, dan

15 Ritchie, Jane dan Jane Lewis (ed). Qulitative Research Practice: A Guide for Social Science Students and Researches, (London: Sage Publication, 2003).

16 Samuel H. Huntington, "Mereformasi Hubungan Sipil-militer", dalam Larry Diamond dan Marc F. Plattner (ed), Hubungan Sipil-Militer dan Konsolidasi Demokrasi, Terj. Tri Wibowo Busi Santoso (Jakarta: PT RajaGrafindo, 2001), h. 4.

17 Samuel H. Huntington, Prajurit dan Negara: Teori dan Politik Hubungan Militer-Sipil, Terj. Deasy Sinaga (Jakarta: PT Grasindo, 2003), h. 91. 
Mhd. Alfahjri Sukri: Perbandingan Hubungan Sipil-Militer Di Indonesia Pada Masa Abdurrahman Wahid Dengan Erdogan Di Turki

membuat militer lebih dekat kepada sektor sipil. $^{18}$

Dalam pandangan Michael $\mathrm{C}$. Desch, indikator yang paling baik dari kondisi sipil adalah siapa yang lebih dominan ketika terjadi perbedaan pilihan atau preferensi antara pihak sipil dan militer. Kalau yang lebih kuat adalah militer, maka akan ada persoalan, tetapi kalau yang kuat adalah sipil, maka tidak ada persoalan. Dalam menentukan apakah militer memainkan peranan penting dalam pengambilan keputusan politik dari masyarakat, maka harus diidentifikasi sejumlah isu yang mejadi pertentangan antara sipil dan militer, serta memperlihatkan siapa yang lebih kuat atau dominan dalam hubungan tersebut. ${ }^{19}$

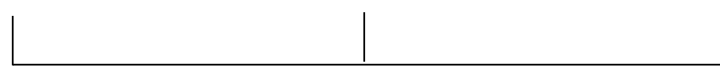

\begin{tabular}{|c|c|c|}
\hline $\begin{array}{l}\text { Paling Lemah } \\
\text { Buruk) Preferens }\end{array}$ & Campuran & $\begin{array}{c}\text { Paling Kuat (Baik) } \\
\text { Preferensi Sipil }\end{array}$ \\
\hline Militer Unggul & & Ungoul \\
\hline
\end{tabular}

Gambar 1. Ukuran Kontrol Sipil (Variabel

Dependent $)^{20}$

Dalam mengemukakan teori kontrol sipil atas militer, Desch menggunakan pendekatan struktural

18 Michael C. Desch, “Ancaman Lingkungan dan Misi Militer", dalam Larry Diamond dan Marc F. Plattner (ed), Oh.cit, h. 22.

${ }^{19}$ Michael C. Desch, Politisi VS Jenderal: Kontrol Sipil atas Militer di Tengah Arus yang Bergeser, Terj. Tri Wibowo Budi Santoso, (Jakarta: PT. Raja Grafindo Persada, 2002), h. 6.

${ }^{20}$ Michael C. Desch, Politisi...h..8. fungsional dengan menggunakan variabel independent yaitu ancaman, yang nantinya akan mempengaruhi sosok pemimpin, organisasi militer, negara dan masyarakat saat merespon ancaman domestik dan internasional. Variabel ancaman, dapat berupa ancaman eksternal (internasional) atau internal (domestik) terhadap negara dan bisa bervariasi dalam intensitasnya. Variabel-variabel tersebut akan mempengaruhi tiga aktor utama dalam ancaman domestik: militer, pemerintah sipil, dan seluruh masyarakat. Adapun ancaman eksternal akan mempengaruhi negara termasuk militer biasanya akan menyebabkan menguatnya kesatuan dalam negara, dan membuat perhatian semua orang akan tertuju keluar. Adapun lingkungan struktural yang mengancam, akan mempengaruhi karakter dari pemimpin sipil, sifat dari institusi militer, keutuhan institusi negara, metode kontrol sipil, konvergensi atau divergensi ide-ide, dan kultur sipil dengan militer. ${ }^{21}$

Michael C. Desch, mengungkapkan empat bentuk dari analisis dalam melihat hubungan sipil-militer. Pertama, tingginya ancaman eksternal, dan rendahnya ancaman internal, maka kontrol sipil lebih 'kuat'. Kedua, tingginya tingkat ancaman eksternal dan tingginya ancaman internal,

21 Michael C. Desch, "Ancaman Lingkungan dan Misi Militer", dalam Larry Diamond dan Marc F. Plattner (ed)., h.19-22. 
akan menghasilkan kontrol sipil yang lemah. Ketiga, rendahnya tingkat ancaman eksternal, dan tingginya ancaman internal, akan menghasilkan kontrol sipil yang lemah. Keempat, rendahnya tingkat ancaman ekternal dan ancaman internal, dapat disebut sebagai kontrol sipil 'campuran'. 22

Dalam empat bentuk analisis yang dikemukakan oleh Desch, dapat dikatakan bahwa kontrol sipil akan kuat apabila ancaman eksternal tinggi dan ancaman internal rendah. Dalam pandangan Desch, kontrol sipil tidak hanya dibutuhkan untuk memelihara kebebasan domestik, tetapi kontrol sipil juga melahirkan kebijakan nasional yang lebih baik, dikarenakan pemimpin sipil tidak terlalu tunduk kepada bias-bias organisasional dan memiliki perspektif yang lebih "nasional" tentang isu-isu petahanan. ${ }^{23}$

Pendapat Desch ini diperkuat oleh pandangan Stanislav Andreski yang menyimpulkan bahwa ancaman eksternal akan membuat militer bekerja, dan kemudian dengan sendirinya militer akan keluar dari politik. Teori Desch ini hanya menggambarkan kondisi-kondisi umum yang membuat kontrol sipil atas militer bisa memburuk atau meningkat. ${ }^{24}$ Dan teori ini dijadikan sebagai pisau analisis

${ }^{22}$ Michael C. Desch,... h. 20-23.

${ }^{23}$ Michael C. Desch,...h. 20-23

24 Tiara Sarah Putri Sumantri....h. 19. 1920. dalam membandingan hubungan sipilmiliter di Indonesia pada masa Abdurrahman Wahid (1999-2001) dan Turki pada masa Recep Tayyib Erdogan (2003-2011).

\section{Pembahasan}

Kontrol Sipil atas Militer di Indonesia (Pada Masa Abdurrahman Wahid)

Abdurrahman Wahid (Gus Dur) terpilih menjadi Presiden Indonesia melalui Sidang Istimewa MPR yang demokratis yang merupakan lembaga perwakilan tertinggi negara saat itu. Wakil Presidennya adalah Megawati Sukarnoputri. Pembentukan Pemerintahan baru dilakukan oleh Gus Dur pada akhir bulan Oktober 1999. Harapan besar ada pada pundak Gus Dur untuk membentuk pemerintahan yang bersih dan mengontrol militer. Pada masa ini juga terjadi beberapa "konflik horizontal" di Poso, Ambon, Sampit (Kalimantan Tengah), Aceh, dan Irian Jaya. ${ }^{25}$

Beberapa hal dilakukan Gus Dur untuk menghidupkan supremasi sipil, menundukkan militer dalam kontrol sipil. Tindakan-tindakan berani diambil oleh Gus Dur, seperti 1) Gus Dur menggangkat Laksamana Widodo AS (dari Angkatan Laut) sebagai pimpinan tertinggi TNI yang

${ }^{25}$ Yahya A. Muhaimin., Oh.cit, h. xxivXXv. 
Mhd. Alfahjri Sukri: Perbandingan Hubungan Sipil-Militer Di Indonesia Pada Masa Abdurrahman Wahid Dengan Erdogan Di Turki

biasanya diisi oleh Jenderal Angkatan

Darat; 2) Jabatan Menteri Pertahanan dan

Keamanan diberikan kepada sipil yaitu Juwono Soedarsono yang merupakan Mendikbud di masa Pemerintah B.J. Habibie dan mantan Wakil Gubernur Lemhanas; 3) Jabatan Kepala Badan Intelijen Strategis (BAIS) yang biasa diisi oleh Angkatan Darat, diserahkan kepada Angkatan Udara; ${ }^{26}$ 4) Pemecatan Jenderal Wiranto dari jabatan Menteri Koordinator dan Politik oleh Gus Dur (terkait kasus HAM di Timtim); 5) Dukungan Gus Dur terhadap Agus Wirahadikusumah untuk memimpin TNI Angkatan Darat, yang mendapat penolakan dari Angkatan Darat (banyak ditolak oleh kubu Wiranto). ${ }^{27}$ Tindakan-tindakan Gus Dur ini memperlihatkan keinginan Gus Dur untuk mengontrol militer.

Namun, ternyata kebijakan Gus Dur yang terlalu campur tangan dalam urusan militer mengakibatkan malapetaka bagi Gus Dur sendiri. Skandal Badan Urusan Logistik (Bulog) menyeret nama Gus Dur, serta tingkah laku politiknya yang dinilai telah melecehkan elite politik yang sebelumnya mendukungnya, mengakibatkan ia jatuh dari kekuasaan. Di tambah dengan Dekrit Presiden 22 Juli 2001 yang dikeluarkannya untuk

\footnotetext{
${ }^{26}$ Indria Samego, TNI di Era Perubahan, (Jakarta: Erlangga, 2000), h. 125-126.

${ }^{27}$ Salim Said., ... h. 211.
}

membubarkan MPR dan DPR tidak didukung oleh militer. $^{28}$ Hal ini mengakibatkan Gus Dur dipecat oleh MPR karena dianggap melanggar konstitusi.

Berdasarkan pada teori yang dikemukakan oleh Michael C. Desch tentang kontrol sipil atas militer, bahwa kontrol sipil kuat kalau ancaman internal menurun, dan ancaman eksternal meningkat. Dan kontrol sipil lemah kalau ancaman internal meningkat, dan ancaman eksternal turun.

Sepanjang kepemimpinan Abdurrahman Wahid (1999-2001), kondisi internal negara tidak berada dalam keadaan kondusif (ancaman internal tinggi). Ancaman internal yang tinggi ini diakibatkan oleh adanya konflik horizontal di daerah-daerah, campur tangan Gus Dur dalam militer yang menghasilkan ketegangan antara Gus Dur dengan kelompok militer Wiranto, elite politik yang tidak lagi mendukung Gus Dur, korupsi Bulog menyeret Gus Dur, serta upaya pembubaran MPR dan DPR melalui dekrit presiden yang dikeluarkan oleh Gus Dur. Hal inilah yang mengakibatkan salah satu faktor sistem politik yang dibangun Gus Dur tidak berjalan, karena dukungan yang mulai berkurang serta tekanan yang dilakukan oleh kelompok militer dan elite

\footnotetext{
28 Dewi Fortuna Anwar dkk, Gus Dur Versus Militer: Studi Tentang Hubungan SipilMiliter di Era Transisi, (Jakarta: PT Grasindo, 2002), h. 83.
} 
politik di MPR dan DPR. Sedangkan kondisi eksternal tidak menandakan ancaman yang berarti.

Hal ini menggambarkan di akhir masa kepemimpinan Gus Dur, bahwa ancaman internal tinggi, dan ancaman eksternal rendah yang mengakibatkan kontrol sipil atas militer lemah. Terbukti dengan masih kuatnya militer dalam mengontrol perpolitikan di dalam negeri untuk menjatuhkan Gus Dur dari kekuasaaan. Kecerobohan dan ketergesagesaan Gus Dur menjadi bumerang bagi dirinya sendiri, sehingga terjungkal dari kekuasaan.

\section{Kontrol Sipil atas Militer di Turki (Pada Masa Erdogan)}

Tahun 2002, AKP pimpinan Erdogan memenangi Pemilu Turki, dan kemenangan ini terjadi disaat Turki memulai kembali perundingan secara serius untuk menjadi anggota penuh Uni Eropa (UE) pada awal 2003. Erdogan menjadi Perdana Menteri pada 14 Maret 2003. Sejak saat itulah Erdogan melakukan reformasi di bidang politik, ekonomi, sosial, dan hukum, dengan dalih untuk memenuhi standar yang ditetapkan oleh UE sebagai syarat menjadi anggota penuh Uni Eropa. Dalih ini dijadikan tameng oleh Erdogan untuk mulai mengurangi peran militer dalam politik serta menjaga stabilitas negara sesuai dengan permintaan Uni Eropa. ${ }^{29}$

Untuk memenuhi syarat untuk menjadi keanggotaan Uni Eropa, Turki melakukan implementasi beberapa kebijakan sesuai dengan kriteria Kopenhagen, seperti penghapusan hukuman mati, mengurangi peran militer dalam Dewan Kemanan Nasional (DKN), memungkinkan adanya siaran televisi yang berbahasa Kurdi, melakukan kontrol anggaran militer oleh sipil, meningkatkan hubungan dengan negara tetangga serta menyelesaikan masalah Siprus. ${ }^{30}$

Pada masa awal kepemimpinan Erdogan, permasalahan eksternal mulai muncul yaitu tuntutan penyelesaian konflik Turki dengan Yunani berkaitan dengan Siprus sebagai syarat pemenuhan keanggotan Turki di UE, dan invansi AS ke Irak yang dikhawatirkan mendorong pembentukan negara Kurdi Turki. Dalam mengatasi permasalahan tersebut Erdogan bekerjasama dengan militer dengan meminta ijin militer, walaupun pada militer menolak kerjasama Turki dengan AS dalam menempatkan pangkalannya di wilayah utara sebagai gerbang perang AS ke Irak. Awalnya permohonan ini ditolak oleh parlemen Turki pada 1 Maret 2003,

${ }^{29}$ M. Hamdan Basyar... h. 88.

30 Firman Maulana Noor, "Transformasi Gerakan Partai Berbasis Islam di Turki: Studi Kasus Perkembangan Adelet Ve Kalkinma Partisi (AKP)," Jurnal Middle East and Islamic Studies, Vol. 4 No. 2 (2017). 
namun kemudian dikabulkan diakhir tahun 2003. ${ }^{31}$ Hal ini menandakan perubahan hubungan sipil-militer yang dimenangkan oleh sipil, dan Erdogan tetap menghormati militer.

Memasuki periode 2005-2007, kondisi eksternal Turki terbilang aman karena menurunnya tuntutan terhadap penyelesaian status Siprus pasca referendum 'Rencana Annan', dan juga krisis Irak yang berubah menjadi hubungan komersil dengan pemerintah baru Irak. Menjadi permasalahan adalah kondisi internal dengan suku Kurdi di Turki setelah perundingan Luksemburg 3 Oktober 2005. Dari 2005 sampai musim semi 2007 hukum keadaan berperang diberlakukan di empat provinsi mayoritas suku Kurdi. ${ }^{32}$ Dalam hal ini Erdogan mengandalkan kekuataan militer untuk mengatasi masalah tersebut.

Kontrol sipil yang kuat atas militer terlihat pada tahun 2010, ketika amademen konstitutional disetujui oleh 58 persen suara referendum yang dilakukan pada 12 September 2010. Paket amademen meliputi pasal yang mengizinkan keputusan Supreme Military Council (YAS) yang salah satu isinya mengenai pemberhentian perwira militer untuk ditindak lanjuti dalam pengadilan. Pada 286.

31 Tiara Sarah Putri Sumantri...h. 229-

32 Tiara Sarah Putri Sumantri...h. 231236.
Februari 2010, pemerintah menghapus Protocol on Cooperation for Security and Public Order (EMASYA) yang sebelumnya telah mengizinkan militer untuk mengintervensi persoalan keamanan domestik berdasarkan inisiatif sendiri. Dan pada agustus 2010, YAS mengeluarkan surat perintah penahanan terhadap 102 perwira, 11 jenderal dan laksamana, serta Juli 2011 Jenderal Isik Kosaner meletakkan jabatannya. ${ }^{33}$ Kebijakankebijakan Erdogan berhasil memasukkan militer kembali ke barak dengan aturan yang telah di amademen. Hal ini menunjukkan kontrol sipil yang kuat atas militer, walaupun saat itu kondisi eksternal Turki dalam ancaman yang rendah. Namun pemerintah selalu menang preferensi dibandingkan militer.

Keberhasilan Erdogan mengirim kembali militer ke barak tidak lepas dari gaya kepemimpinannya serta jaringan media yang dia miliki. Erdogan menjalin kerjasama dengan pengusaha-pengusaha muslim yang kemudian bersatu dalam asosiasi bisnis yaitu MUSIAD (Mustakil Sanayici ve Isadamlari Dernegi). MUSIAD didirikan tahun 1990 yang sifatnya non-profit, non-pemerintahan, dan berbasis sukarela yang telah memberikan

33 Tiara Sarah Putri Sumantri...h. 266271. 
kontribusi untuk pendapatan ekspor Turki, juga berkontribusi terhadap PDB Turki. ${ }^{34}$

Erdogan juga memiliki kekuatan media yang kuat, sehingga dapat mempengaruhi persepsi masyarakat. Surat kabar tersebut adalah Zaman yang telah mencapai sirkulasi nasional terbesar (700.000) yang telah mempublikasikan tulisan-tulisan kritis yang ditulis oleh cendikiawan-cendikiawan ternama untuk mengkritisi CHP, Militer, dan Mahkamah Konstitusi pada saat pemilihan presiden tahun 2007. Ketika militer ingin meluncurkan suatu kudeta kalau Abdullah Gul terpilih menjadi presiden, karena Gul dan AKP dianggap membawa nilai-nilai Islam, maka Zaman dan media lainnya secara aktif mengkampanyekan pemilihan Abdullah Gul, dan juga penolakan akan adanya intervensi militer. ${ }^{35}$

Selama Erdogan memimpin, ekonomi Turki terus meningkat. Tahun 2011 Produk Domestik Bruto Turki mencapai triliyunan dolar sehingga ia menjadi negara ke 16 dalam kekuatan ekonomi dunia. Di Eropa, Turki adalah negara ke-7 dalam kekuatan ekonomi. Nilai ekspor Turki ke dunia Islam meningkat dari 11 dolar menjadi 60 milyar dolar, dan jumlah hutang Turki ke bank dunia juga mengalami penurunan setiap

\footnotetext{
34 M. Hamdan Basyar... h.89.

35 Tiara Sarah Putri Sumantri... h.256257.
}

tahunnya. ${ }^{36}$ Peningkatan ekonomi inilah menjadi salah satu faktor rakyat menyukai Erdogan dan terbukti dengan kemenangan AKP berturut-turut di 2002, 2007, 2011, dan 2015.

$$
\text { Selama masa kepemimpinan }
$$
Erdogan, upaya untuk melakukan kontrol atas militer dilakukan setahap demi setahap. Adanya kekuatan politik parlemen yang didominasi oleh AKP, dukungan dari kelompok kepentingan, dan dukungan rakyat, mengakibatkan kontrol sipil atas militer semakin kuat. Militer semakin di dorong untuk masuk ke barak. Gaya kepemimpinan Erdogan juga mempengaruhi relasi sipil-militer ini.

Berdasarkan teori Michael C. Desch bahwa kontrol sipil kuat kalau ancaman internal menurun, dan ancaman eksternal meningkat. Dan kontrol sipil lemah kalau ancaman internal meningkat, dan ancaman eksternal turun.

Sepanjang kepemimpinan Erdogan (2003-2011), terjadi pola hubungan sipil militer yang terus menunjukkan kekuatan sipil. Di awal kepemimpinannya, Erdogan sebenarnya telah memiliki langkah awal untuk mengontrol militer, walaupun ia belum belakukannya secara radikal. Kondisi eksternal yang tinggi akibat konflik Siprus, invasi AS ke Irak, serta

36 Jhon Afrizal, "Gerakan Sosial Politik Islam Dunia (Asas Perubahan Skenario Politik Negara)," Jurnal Sosial Budaya, Vol. 9, No. 1 (2012), h. 148. 
Mhd. Alfahjri Sukri: Perbandingan Hubungan Sipil-Militer Di Indonesia Pada Masa Abdurrahman Wahid Dengan Erdogan Di Turki

perundingan dengan UE menimbulkan tingkat ancaman yang tinggi, dan sebaliknya kondisi Internal Turki dalam ancaman rendah. Ternyata hal ini tidak otomatis memperlihatkan kontrol sipil yang kuat, karena adanya penolakan oleh militer tentang ijin penempatan pangkalan AS di wilayah utara sebagai gerbang perang AS ke Irak, serta parlemen yang sempat menolak usulan Erdogan tersebut. Namun, disini Erdogan bermain, dengan memainkan politiknya di parlemen sehingga usulannyapun lolos. Hal ini menunjukkan preferensi sipil menang atas milik, dan kontrol sipil kuat atas militer. Namun, Erdogan tetap menghormati militer.

Kontrol sipil atas militer yang betul-betul kuat terlihat sejak 2010, walaupun ancaman eksternal rendah, dan ancaman internal rendah, tetapi tetap menghasilkan kontrol sipil yang kuat, karena preferensi sipil yang selalu menang atas militer. Terbukti dari kemenangan atas referendum amademen konstitusi serta penangkapan atas perwira militer yang diduga terlibat kudeta. Kuatnya kontrol sipil atas militer tak lepas dari dukungan rakyat, dominasi politik AKP di parlemen, serta peranan media.

Analisis Perbandingan Kontrol Sipil atas Militer di Indonesia Pada Masa Abdurrahman Wahid (1999-2001) dan Turki Pada Masa Erdogan (2003-2011) 141
Dalam melakukan analisis perbandingan ini, digunakan pendekatan struktural fungsional dengan teori kontrol sipil atas militer yang dikemukakan Michael C. Desch (variabel dependent dan independent). Dengan melihat bahwa tinggi rendahnya ancaman internal bisa dilihat dari situasi politik, peran pemimpin, peran militer, partai politik, serta kelompok kepentingan. Ancaman eksternal hanya dilihat dari ancaman-ancaman yang dapat menyebabkan bahaya pada negara.

Terdapat perbedaan dan persamaan kontrol sipil atas militer yang terjadi di Indonesia (Abdurrahman Wahid) dengan Turki (Erdogan). Di awal pemerintahannya Gus Dur mendapat dukungan politik dari parpol maupun militer karena ia terpilih secara demokratis melalui Sidang Istimewa MPR. Tindakan-tindakan yang diambil oleh Gus Dur adalah untuk memperkuat kontrol sipil atas militer, yang bisa dikatakan sebagai tindakan yang radikal karena dengan adanya indikasi penolakan oleh militer. Tindakan Gus Dur ini berbeda dengan tindakan yang dilakukan oleh Erdogan. Erdogan memperkuat kontrol sipil atas militer dengan cara perlahan.

Tingkat ancaman internal di awal pemerintahan masing-masing presiden berbeda yaitu di awal pemerintahan Gus Dur, tingkatan ancaman internal tinggi, dan di masa Erdogan, tingkat ancaman 
rendah. Adapun tingkat ancaman eksternalnya berbeda, yaitu di awal pemerintahan Gus Dur ancaman eksternal rendah, dan dimasa Erdogan, tingkat ancaman tinggi. Di masa Gus Dur, kondisi perpolitikan dan perekonomian masih belum stabil, dan konflik horizontal yang terjadi dibeberapa wilayah, adapun di masa Erdogan, pemerintahannya fokus pada pemulihan ekonomi dan demokrasi. Di lingkungan eksternal, tidak ada ancaman berarti bagi pemerintahan Gus Dur, adapun Erdogan, tingkat ancaman eksternal tinggi karena penyeleseian konflik Siprus, serta adanya invasi AS ke Irak, dan fokus pemerintah untuk bisa bergabung dengan Uni Eropa.

Berdasarkan teori Michael C. Desch, tingkat ancaman internal yang tinggi disertai tingkat ancaman eksternal yang rendah akan menghasilkan kontrol sipil atas militer yang lemah, dan sebaliknya ketika tingkat ancaman internal rendah, dan tingkat ancaman eksternal tinggi akan menghasilkan kontrol sipil yang kuat. Kontrol sipil juga dikatakan kuat apabila preferensi sipil lebih kuat dari militer, dan sebaliknya kontrolnya akan lemah apabila preferensi militer lebih kuat.

Di awal pemerintahan Gus Dur, kontrol sipil atas militer mulai menuju ke arah yang kuat karena kondisi perpolitikan saat itu, dimana masyarakat tidak lagi menghendaki militer ada dalam sistem politik, serta penghapusan Dwifungsi ABRI yang mengakibatkan berkurangnya kekuatan politik militer dimasa itu, namun militer masih memiliki kekuatan politik melalui fraksi tentara dan polisi di DPR. Ancaman internal yang tinggi dan ancaman eksternal yang rendah ternyata tidak menghasilkan kontrol sipil atas militer yang lemah, hal ini dikarenakan kondisi perpolitikan saat itu, serta masih adanya dukungan politik kepada Gus Dur, baik dari parlemen, maupun masyarakat. Hal ini terbukti dengan tindakan-tindakan Gus Dur dalam kebijakannya yang melakukan berbagai perubahan dalam militer.

Kontrol sipil dikatakan kuat apabila preferensi sipil lebih kuat dibandingkan militer, diperlihatkan Gus Dur ketika pengangkatan Laksamana Widodo AS (dari Angkatan Laut) sebagai pemimpin tertinggi TNI yang biasanya diisi oleh Jenderal Angkatan Darat, jabatan Menteri Pertahanan dan Keamanan oleh Prof. Juwono Soedarsono yang merupakan kalangan sipil, dan perubahan lainnya yang dilakukan oleh Gus Dur secara berani. Dalam hal ini militer tidak bisa melakukan apa-apa, yang artinya preferensi sipil menang atas militer yang menandakan kontrol sipil yang kuat atas militer. Gus Dur ingin memperlihatkan bahwa ia memiliki kekuatan untuk mengontrol militer. 
Mhd. Alfahjri Sukri: Perbandingan Hubungan Sipil-Militer Di Indonesia Pada Masa Abdurrahman Wahid Dengan Erdogan Di Turki

Kontrol sipil yang kuat atas militer juga terlihat di awal pemerintahan Erdogan. Dengan dalih keinginan Turki untuk menjadi anggota UE, Erdogan membuat kebijakan-kebijakan yang secara perlahan melemahkan posisi militer untuk ikut campur dalam politik. Serta perbedaan-perbedaan pandangan militer dengan Erdogan yang selalu dimenangkan oleh Erdogan menunjukkan kontrol sipil menuju ke arah yang kuat atas militer (preferensi sipil selalu menang, menandakan kontrol sipil yang kuat). Hal ini tak terlepas dari tingkat ancaman eksternal yang tinggi, dan ancaman internal yang rendah. Dan juga tak terlepas dari mesin politik Erdogan yaitu AKP dan gaya kepemimpinannya yang tetap menghormati militer.

Tabel 1. Kontrol sipil atas militer di awal masa kepemimpinan

\begin{tabular}{llllll}
$\begin{array}{l}\text { Awal } \\
\text { Masa } \\
\text { Kepemim } \\
\text { pinan }\end{array}$ & $\begin{array}{l}\text { Tingkat } \\
\text { Ancam } \\
\text { an } \\
\text { Internal }\end{array}$ & $\begin{array}{l}\text { Tingkat } \\
\text { Ancaman } \\
\text { Eksternal }\end{array}$ & $\begin{array}{l}\text { Prefere } \\
\text { nsi Sipil }\end{array}$ & $\begin{array}{l}\text { Prefere } \\
\text { nsi } \\
\text { Militer }\end{array}$ & $\begin{array}{l}\text { Kontrol } \\
\text { Sipil } \\
\text { atas } \\
\text { Militer }\end{array}$ \\
\hline $\begin{array}{l}\text { Abdurrah } \\
\text { man }\end{array}$ & Tinggi & Rendah & Menang & Kalah & Kuat \\
$\begin{array}{l}\text { Wahid } \\
(2001)\end{array}$ & & & & & \\
\hline $\begin{array}{l}\text { Erdogan } \\
(2003)\end{array}$ & Rendah & Tinggi & Menang & Kalah & Kuat \\
\hline
\end{tabular}

Diawal kepemimpinan Gus Dur dan Erdogan, hubungan sipil-militer kedua negara sama-sama menempatkan kontrol sipil yang kuat atas militer. Dukungan politik dari parlemen dan masyarakat membuat dua tokoh ini memiliki kekuatan untuk mengontrol militer.

Perbedaan terlihat akhir pemerintahan, yaitu kontrol sipil yang lemah di masa akhir pemerintahan Gus Dur, dan sebaliknya kuat di masa Erdogan. Di akhir pemerintahan Gus Dur, tingkat ancaman internal tinggi, diakibatkan oleh masih terjadinya konflik horizontal, campur tangan Gus Dur dalam militer yang mendapat penolakan dari militer kubu Wiranto, hilangnya kekuatan politik yang dimiliki oleh Gus Dur di parlemen, terjeratnya Gus Dur dalam kasus Bulog, hilangnya dukungan dari elite politik, serta gagalnya dekrit presiden yang dikeluarkan oleh Gus Dur yang tidak didukung oleh militer. Saat itu, ancaman eksternal rendah. Dan hal ini mengkonfirmasi teori Desch, tingkat ancaman internal tinggi dan ancaman eksternal rendah, menghasilkan kontrol sipil yang lemah. Lemahnya kontrol sipil juga bisa dilihat dari kalahnya preferensi sipil dari militer.

Tabel 2. Kontrol Sipil atas Militer di Akhir Kepemimpinan

\begin{tabular}{|c|c|c|c|c|c|}
\hline $\begin{array}{l}\text { Akhir Masa } \\
\text { Kepemimpinan }\end{array}$ & $\begin{array}{l}\text { Tingkat } \\
\text { Ancaman } \\
\text { Internal }\end{array}$ & $\begin{array}{l}\text { Tingkat } \\
\text { Ancaman } \\
\text { Eksternal }\end{array}$ & $\begin{array}{l}\text { Preferensi } \\
\text { Sipil }\end{array}$ & $\begin{array}{l}\text { Preferensi } \\
\text { Militer }\end{array}$ & $\begin{array}{l}\text { Kontrol } \\
\text { Sipil } \\
\text { atas } \\
\text { Militer }\end{array}$ \\
\hline
\end{tabular}

\begin{tabular}{llllll}
\hline Abdurrahman & Tinggi & Rendah & Kalah & Menang & Lemah \\
Wahid (2000- & & & & & \\
2001) & & & & & \\
& & & & & \\
\hline $\begin{array}{l}\text { Erdogan (2010- } \\
\text { 2011) }\end{array}$ & Rendah & Rendah & Menang & Kalah & Kuat
\end{tabular}
2011) 
Di masa akhir pemerintahan Gus Dur, ancaman internal tinggi dan ancaman eksternal rendah, mengakibatkan kontrol sipil atas militer lemah. Adapun kalahnya preferensi sipil dari militer bisa dilihat dari kekalahan Gus Dur dalam mengusung Agus Wirahadikusumah untuk memimpin TNI Angkatan Darat yang mendapat penolakan dari Angkatan Darat. Dan juga dekrit presiden yang dikeluarkan Gus Dur, namun menghasilkan penolakan oleh militer menunjukkan bahwa militer tidak mau tunduk pada Gus Dur. Hal ini berbeda ketika Sukarno mengeluarkan dekrit presiden yang didukung oleh militer. Tindakan militer ini menunjukkan kemenangan preferensi militer ketika menghadapi masalah, adapun preferensi sipil adalah lemah.

Berbeda dengan Erdogan yang kontrol sipil atas militer semakin kuat. Hal ini dipengaruhi oleh ancaman internal yang rendah, walaupun ancaman eksternal juga rendah. Rendahnya tingkat ancaman internal juga dipengaruhi oleh gaya kepemimpinan Erdogan, stabilitas ekonomi yang dibangun oleh Erdogan sehingga ia selalu mendapat dukungan dari rakyat (terbukti dari kemenangan AKP di tahun 2011), peran dari kelompok kepentingan seperti media dan pengusaha yang selalu mendukung Erdogan, serta dominasi politik yang dilakukan oleh partai Erdogan yaitu AKP sehingga tindakannya didukung oleh parlemen.

Tingkat ancaman internal yang rendah, dan ancaman eksternal yang juga rendah, ternyata menghasilkan kontrol militer yang kuat, karena preferensi sipil selalu menang atas militer. Hal ini terlihat dari kemenangannya di referendum amademen konstitusi untuk mengubah peraturan-peraturan mengenai militer, serta tindakan Erdogan yang menjebloskan perwira militer dan orang-orang yang dianggap terlibat dalam percobaan kudeta.

Terdapat perbedaan antara Gus Dur dan Erdogan, hal ini sangat dipengaruhi oleh gaya kepemimpinan masing-masing presiden, dan memberikan hasil yang berbeda. Gus Dur gagal dalam memperkuat kontrol sipil atas militer di masanya, adapun Erdogan berhasil memperkuat kontrol sipil atas militer, dan bahkan membuat militer kembali ke barak. Tindakan radikal Gus Dur menghasilkan kegagalan, dan tindakan sabar yang dilakukan erdogan memberikan keberhasilan. Gaya kepemimpinan sangat mempengaruhi kontrol sipil atas militer di masing-masing negara.

Teori Michael C. Desch ini memang belum sepenuhnya mampu menjelaskan fenomenan yang terjadi di Indonesia dan Turki, hal ini juga dipengaruhi oleh kondisi perpolitikan 
Mhd. Alfahjri Sukri: Perbandingan Hubungan Sipil-Militer Di Indonesia Pada Masa Abdurrahman Wahid Dengan Erdogan Di Turki

dimasing-masing negara serta gaya kepemimpinan masing-masing pemimpin. Namun, hal ini dapat ditutupi dengan adanya variabel dependent yang dikemukakan Desch.

\section{Penutup}

Dalam perbandingan hubungan sipil-militer antara Indonesia pada kepemimpinan Presiden Gus Dur (19992001) dengan Erdogan (2003-2011) di Turki dapat dilihat dari kontrol sipil atas militer. Dalam perbandingannya terdapat perbedaan maupun persamaan. Persamaan hubungan sipil-militer di Indonesia pada masa Gus Dur dan Turki pada masa Erdogan, adalah memiliki kontrol sipil yang kuat dimasa awal pemerintahan Abdurrahman Wahid (1999) dan Erdogan (2003). Dengan politik kepada dua tokoh ini membuat kontrol sipil atas militer kuat. Adapun perbedaannya terletak di akhir pemerintahan Gus Dur dan Erdogan, dimana di akhir pemerintahan Gus Dur (2000-2001), kontrol sipil melemah. Sedangkan di masa Erdogan, kontrol sipil semakin menguat.

\footnotetext{
Kegagalan Gus Dur dalam mengontrol militer diakhir pemerintahannya, diakibatkan dari gaya kepemimpinannya yang ingin memperkuat kontrol sipil atas militer secara radikal. Sehingga, militer yang saat itu masih memainkan peranan dalam perpolitikan di 145
}

Indonesia tidak mendukung kebijakannya serta ditambah dengan berbagai kasus yang menimpa pemerintahan dan elit politik yang tidak lagi mendukung pemerintahan Gus Dur. Adapun keberhasilan Erdogan mengubah kontrol sipil atas militer dilakukan secara bertahap. Ia tetap menghormati posisi militer tetapi secara bertahap mengurangi peranan militer dalam politik dengan berbagai kebijakannya. Tindakannya juga mendapatkan dukungan politik, kelompok kepentingan dan masyarakat. Penelitian ini menyarankan agar pemerintah Indonesia dapat belajar dari kesalahan yang dilakukan oleh Gus Dur serta belajar dari gaya kepemimpinan Erdogan untuk membentuk kontrol sipil yang kuat atas militer di Indonesia.

\section{Pustaka Acuan}

Afrizal, Jhon, "Gerakan Sosial Politik Islam Dunia (Asas Perubahan Skenario Politik Negara)", Jurnal Sosial Budaya, Vol. 9, No. 1, 2012.

Anwar, Dewi Fortuna dkk. Gus Dur Versus Militer: Studi Tentang Hubungan Sipil-Militer di Era Transisi. Jakarta: PT Grasindo, 2002.

Basyar, M. Hamdan. Pertarungan dalam Berdemokrasi. Jakarta: UI-Press, 2015.

Desch, Michael C. Politisi VS Jenderal: Kontrol Sipil atas Militer di Tengah 
Arus yang Bergeser. Jakarta: PT. Raja Grafindo Persada, 2002.

Diamond, Larry dan Marc F. Plattner (ed).

Hubungan Sipil-Militer dan

Konsolidasi Demokrasi. Jakarta: PT

RajaGrafindo, 2001.

Fatgehipon, Abdul Haris. Tentara dan

Pergolakan Politik Indonesia:

Membongkar Mitos Melanjutkan

Reformasi Internal. Jakarta: Cahaya

Pineleng, 2010.

Hidayat, Syahrul. Mengislamkan Negara

Sekuler. Jakarta: Prenadamedia Group, 2015.

Huntington, Samuel P. Prajurit dan Negara: Teori dan Politik Hubungan Militer-Sipil. Alih Bahasa Deasy Sinaga. Jakarta: PT Grasindo, 2003.

Muhaimin, Yahya A. Perkembangan Militer Dalam Politik Indonesia 1945-1966. Yogyakarta: Gadjah Mada University Press, 2002.

Noor, Firman Maulana. "Transformasi Gerakan Partai Berbasis Islam di Turki: Studi Kasus Perkembangan Adelet Ve Kalkinma Partisi (AKP)," Jurnal Middle East and Islamic Studies, Vol. 4 No. 2 (2017).

Putra, Adam Sukarno, Nurul Umamah, dan Sumarno, "The Presiden's Political Policy Abdurrahman Wahid About Indonesia Military Years 1999-2001, Jurnal Historica, Vol. 3 No. 1 (2019).
Ritchie, Jane dan Jane Lewis (ed). Qulitative Research Practice: A Guide for Social Science Students and Researches. London: Sage Publication, 2003.

Said, Salim. Tumbuh dan Tumbangnya Dwifungsi: Perkembangan Pemikiran Politik Militer Indonesia 1958-2000. Jakarta: Aksara Karunia, 2002.

Samego, Indria. TNI di Era Perubahan. Jakarta: Erlangga, 2000.

Siddiq, Mohammad. "Profesionalisme Mi liter Pada Pemerintahan Soeharto dan Abdurrahman Wahid (Kajian Perbandingan Sosial-Historis),” Jurnal Politik dan Sosial Kemasyarakatan, Vol. 11 No. 1 (2019).

Sugiyono. Metode Penelitian Kuantitatif Kualitatif dan $R \& D$. Bandung: Alfabeta, 2012.

Sumantri, Tiara Sarah Putri. Demokratisasi Turki: Hubungan Sipil-Militer Tahun 2003-2011. Jakarta: Universitas Indonesia (UIPress), 2012.

Sundhaussen, Ulf. Politik Militer Indonesia 1945-1967: Menuju Dwi Fungsi ABRI. Jakarta: LP3ES, 1986. 